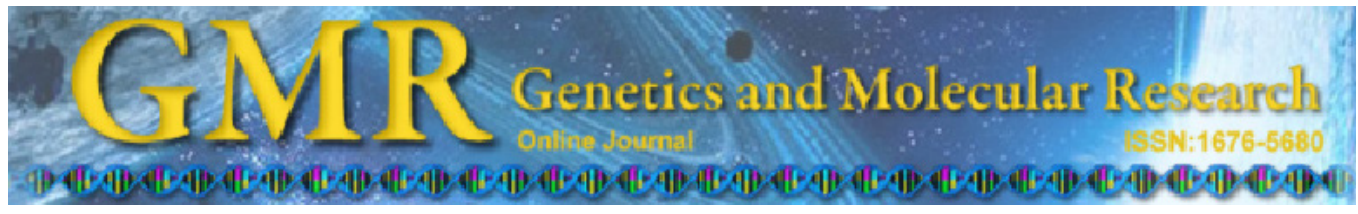

\title{
Allelic database and divergence among Psidium accessions by using microsatellite markers
}

\author{
S.R. da $\operatorname{Costa}^{1}$ and C.A.F. Santos ${ }^{2}$ \\ ${ }^{1}$ Programa em Recursos Genéticos Vegetais, \\ Corresponding author: C.A.F. Santos \\ E-mail: carlosfesantos@hotmail.com \\ Genet. Mol. Res. 12 (4): 6802-6812 (2013) \\ Received May 27, 2013 \\ Accepted October 1, 2013 \\ Published December 16, 2013 \\ DOI http://dx.doi.org/10.4238/2013.December.16.6
} Universidade Estadual de Feira de Santana, Feira de Santana, BA, Brasil

${ }^{2}$ Centro de Pesquisa Agropecuária do Trópico Semiárido, Petrolina, PE, Brasil

\begin{abstract}
This study aimed to investigate the genetic variability among guava accessions and wild Psidium species of the Embrapa Semiárido germplasm collection by using microsatellite loci to guide genetic resources and breeding programs, emphasizing crosses between guava and other Psidium species. DNA was extracted using the $2 \mathrm{X}$ $\mathrm{CTAB}$ method, and polymerase chain reaction products were analyzed on $6 \%$ denatured polyacrylamide gels stained with silver nitrate. The unweighted pair-group method using arithmetic average dendrogram generated from the distance matrix of the Jaccard coefficient for 183 alleles of 13 microsatellite loci was used for visualization of genetic similarity. The number of base pairs was estimated using inverse mobility method based on the regression of known-size products. Analysis of molecular variance was performed using total decomposition between and within guava accessions. The accessions showed similarity from 0.75 to 1.00 , with the dendrogram presenting cophenetic value of 0.85 . Five groups were observed: the first included guava accessions; the second, $P$. guineense accessions; the third, one accession of $P$. friedrichsthalianum; and the last 2 groups, $P$. cattleianum. The genetic similarity among $P$.
\end{abstract}


guineense and some guava accessions were above $80 \%$, suggesting greater possibility to obtain interspecies hybrids between these 2 species. The genetic variability between the accessions was considered to be high $\left(\Phi_{\mathrm{ST}}=0.238\right)$, indicating that guava genetic variability is not uniformly distributed among the 9 Brazilian states from where the accession were obtained. Obtaining a greater number of accessions by Brazilian states is recommended in order to have greater diversity among the species.

Key words: Psidium; Active germplasm bank; Breeding; Dendrogram; AMOVA

\section{INTRODUCTION}

In his overview, Gonzaga Neto (1999) expressed that De Candolle, when studying the guava origin, started by eliminating the old world and arrived at the conclusion that the guava originated in America and only the region it originated needed to be determined. According to De Candolle, the origin of the guava could have been Mexico, Colombia, Peru, or Brazil. According to Risterucci et al. (2005), the guava is native to the north of South America since it is abundantly distributed throughout the tropical American regions.

At present, guava has a well-established market in over 60 countries due to its rustic, prolific character; high level of vitamin C; and great economic return (Negi and Rajan, 2007). The species is abundantly distributed in the tropics and subtropics that people from different countries consider it native to the region (Singh, 2007). Brazil is the third largest producer of commercial guava, possessing edaphoclimatic conditions that favor the production of the fruit. Its cultivation is favored due to the nutrient and functional elements present in the fruit, besides the fact that it is possible to consume the fruit in natura or in the form of sweets and jams, resulting in a great economic return for the producers due to the versatility of its uses (São José et al., 2003; IBGE, 2011).

Among the traditional species of the Myrtaceae family, the guava and araçazeiro are the most important. Although the latter does not have the same economic importance as guava, they are of interest for research because their fruits show desirable characteristics with an exotic flavor and high levels of vitamin C. Furthermore, they are being studied as a source of tolerance to Meloidogyne enterolobii, a pest that has decimated guava orchards (Raseira and Raseira, 1996; Souza et al., 2006). Guava is a species that shows a high genetic diversity, due to the mixed reproductive system, as well as the use of seeds originating from heterozygous genitors for the production of seedlings (Alves and Freitas, 2007; Pessanha et al., 2011).

Pessanha et al. (2011) used the random amplified polymorphic DNA (RAPD) marker to evaluate the genetic diversity among 20 accessions of Psidium. Similarly, Erig et al. (2003) studied the genetic diversity among 24 accessions of araçazeiros by using RAPD markers and separated the genotypes into 4 groups in which the first showed $40 \%$ of similarity with the others, while the largest proximity was found between the last two. However, this marker has a low reproducibility and is dominant (Esselink et al., 2003). Corrêa et al. (2011) studied and compared the genetic similarity of 62 guava and 24 araçazeiro accessions by using amplified fragment length polymorphism (AFLP) markers and separated the genotypes into 2 groups, one formed by guava accessions and another by araçazeiro accessions with the inclusion of some guava accessions, with a similarity ranging from 28 to $98 \%$. 
Valdés-Infante et al. (2007) were the first to report and characterize Cuban guava accessions by using microsatellites. The authors used 7 microsatellite loci that generated 34 different alleles, of which 10 were considered to be rare. Aranguren et al. (2010) identified a high diversity in 31 Venezuelan guava accessions when genotyped with 16 microsatellite loci. Sánchez-Teyer et al. (2010) reported a similarity of 0.64 to 0.97 in 57 Mexican guava accessions genotyped with 6 microsatellite loci. Studies involving the use of microsatellite loci for the characterization of guava germplasm have not yet been reported in Brazil.

The objective of this study was to analyze the genetic variability of guava and wild Psidium (araçazeiros) accessions of the Embrapa Semiárido germplasm collection by using microsatellite markers in order to obtain subsidies for the genetic improvement and resource program for facilitating guava crossing with other species of the genus Psidium.

\section{MATERIAL AND METHODS}

The material was obtained from the Embrapa germplasm collection (BAG) of guava and araçazeiros (Table 1) located at the experimental field at Bebedouro, Embrapa Semiárido, Petrolina, PE. The BAG is divided into 2 blocks consisting of 118 guava and 40 araçazeiro accessions that were collected from 10 Brazilian States: Maranhão, Sergipe, Piauí, Pernambuco, Goiás, Bahia, Roraima, Rondônia, Amazonas, and Rio Grande do Sul. Each accession is represented by 6 plants with $4.0 \times 4.0 \mathrm{~m}$ spacing. The accessions are irrigated 3 times per week by drip irrigation.

\begin{tabular}{|c|c|c|c|c|c|}
\hline Accession & Origin & State & Accession & Origin & State \\
\hline GUA132 RR & Iracema & $\mathrm{RR}$ & GUA117 GO & Morrinhos & GO \\
\hline GUA138 RR & Boa Vista & RR & GUA120 GO & Goiás Velho & GO \\
\hline GUA133 RR & Iracema & $\mathrm{RR}$ & GUA121 GO & Goiás Velho & GO \\
\hline GUA135 RR & Iracema & $\mathrm{RR}$ & GUA124 GO & Santa Isabel & GO \\
\hline GUA136 RR & Rorainópolis & $\mathrm{RR}$ & GUA127 GO & Mimoso de Góias & GO \\
\hline GUA137 RR & Caracaraí & RR & GUA128 GO & Mimoso de Góias & GO \\
\hline GUA34 PE & Ibimirim & PE & GUA87 AM & Iranduba & AM \\
\hline GUA38 PE & Pesqueira & PE & GUA88 AM & Iranduba & AM \\
\hline GUA36 PE & Pesqueira & PE & GUA90 AM & Iranduba & $\mathrm{AM}$ \\
\hline GUA33 PE & Ibimirim & PE & GUA92 AM & Manacapuru & $\mathrm{AM}$ \\
\hline GUA39 PE & Belo Jardim & PE & GUA97 AM & Autazes & $\mathrm{AM}$ \\
\hline GUA161 PE & Petrolina & PE & GUA98 AM & Autazes & $\mathrm{AM}$ \\
\hline GUA51 SE & Capela & PE & GUA62 BA & Antonio Gonçalves & BA \\
\hline GUA61 SE & Riachão dos Dantas & SE & GUA146 BA & Valença & BA \\
\hline GUA55 SE & Pirambu & SE & GUA147 BA & Pateroá & $\mathrm{BA}$ \\
\hline GUA52 SE & Capela & SE & GUA150 BA & Nilo Peçanha & BA \\
\hline GUA53 SE & Japoratuba & SE & GUA151 BA & Nilo Peçanha & BA \\
\hline GUA59 SE & Umbamba & SE & GUA155 BA & Igrapiúna & BA \\
\hline GUA03 MA & Coelho Neto & SE & GUA106 RS & Pelotas & RS \\
\hline GUA02 MA & Caxias & MA & GUA109 RS & Pelotas & RS \\
\hline GUA26 MA & Paraibano & MA & GUA110 RS & Pelotas & RS \\
\hline GUA05 MA & Buriti & MA & GUA104 RS & Pelotas & RS \\
\hline GUA07 MA & Mata Roma & MA & ARA138 RR & Boa Vista & $\mathrm{RR}$ \\
\hline GUA06 MA & Mata Roma & MA & ARA140 RR & Boa Vista & $\mathrm{RR}$ \\
\hline GUA67 RO & Jaru & MA & ARA153 BA & Ituberá & $\mathrm{RR}$ \\
\hline GUA68 RO & Buritis & RO & ARA105 RS & Pelotas & RS \\
\hline GUA72 RO & Monte Negro & RO & ARA55 RS & Pelotas & RS \\
\hline GUA73 RO & Ariquemes & RO & ARA58 RS & Pelotas & RS \\
\hline GUA81 RO & Porto Velho & RO & ARA Costa Rica & - & - \\
\hline GUA82 RO & Porto Velho & RO & Paluma & - & PE \\
\hline
\end{tabular}




\section{Extraction and quantification of DNA}

New and healthy leaves of 61 Psidium accessions were collected in paper bags, duly identified, and conditioned in a freezer at $-80^{\circ} \mathrm{C}$ until DNA extraction.

During DNA extraction, the 2X CTAB of Doyle and Doyle (1990) was used, with the following modifications: A) mechanical maceration was performed in the presence of liquid nitrogen until a fine powder was obtained; B) the macerated leaves of each sample were transferred to duplicated 2-mL Eppendorf tubes, each containing $950 \mu \mathrm{L} 2 \mathrm{X}$ CTAB; C) samples were put in a water-bath at $60^{\circ} \mathrm{C}$ for $30 \mathrm{~min}$ and were gently inverted every $10 \mathrm{~min}$; D) after 30 $\min , 950 \mu \mathrm{L}$ chloroform:isoamyl alcohol (24:1) was added, followed by centrifugation at 6000 rpm for $10 \mathrm{~min}$; E) $700 \mu \mathrm{L}$ supernatant was transferred to new Eppendorf tubes; F) $467 \mu \mathrm{L}$ chilled isopropyl alcohol was added next, and the tubes were gently inverted and maintained on ice for $20 \mathrm{~min} ; \mathrm{G}$ ) after $20 \mathrm{~min}$, the samples were centrifuged at 10,000 rpm for the formation of a "pellet" at the bottom of the tube; $\mathrm{H}$ ) the pellet was re-suspended in $30 \mu \mathrm{L}$ Tris-EDTA and kept in a refrigerator for $24 \mathrm{~h}$ to completely dissolve the pellet; I) the co-extracted RNAs were removed using $10 \%$ RNAse for $45 \mathrm{~min}$ in a water bath at $37^{\circ} \mathrm{C}$.

The DNA was quantified on $0.8 \%$ agarose gel stained with ethidium bromide by visually comparing the intensity of the DNA bands extracted with those of bands of Lambda phage DNA. The samples were diluted to $10 \mathrm{ng} / \mu \mathrm{L}$ and stocked at $-20^{\circ} \mathrm{C}$.

\section{Reaction and amplification of DNA and resolution on polyacrylamide gels}

All 16 SSR loci, suggested by Briceño et al. (2010), were evaluated for guava diversity studies: mPgCIR227, mPgCIR228, mPgCIR229, mPgCIR233, mPgCIR236, mPgCIR242, mPgCIR243, mPgCIR246, mPgCIR247, mPgCIR249, mPgCIR251, mPgCIR252, mPgCIR253, mPgCIR255, mPgCIR256, and mPgCIR257. The PCR amplification was carried out for a final volume of $10 \mu \mathrm{L}$, containing $30 \mathrm{ng}$ DNA, $0.2 \mu \mathrm{L}$ of each primer, $1 X$ Taq DNA polymerase buffer, $2.5 \mathrm{mM} \mathrm{MgCl}, 0.8 \mathrm{mM}$ dNTPs, and $0.75 \mathrm{U}$ enzyme Taq DNA polymerase. The amplification program consisted of denaturation of the initial cycle at $94^{\circ} \mathrm{C}$ for $4 \mathrm{~min} ; 30$ cycles at $94^{\circ} \mathrm{C}$ for $45 \mathrm{~s}, 52^{\circ} \mathrm{C}$ for $60 \mathrm{~s}$, and $72^{\circ} \mathrm{C}$ for $60 \mathrm{~s}$; and one stage of final extension at $72^{\circ} \mathrm{C}$ for $5 \mathrm{~min}$.

Half of the volume of the denaturing buffer of $98 \%$ formamide (10 mM EDTA, $\mathrm{pH} 8.0 ; 1$ $\mathrm{mg} / \mathrm{mL}$ xylene cyanol; and $1 \mathrm{mg} / \mathrm{mL}$ bromophenol blue) was added to the PCR mixture, followed by complete denaturation at $94^{\circ} \mathrm{C}$ for $5 \mathrm{~min}$ in a thermocycler. Amplified PCR products were separated on $6 \%$ polyacrylamide gels for approximately $3 \mathrm{~h}$, with constant $40 \mathrm{~W}$ power. A prerun of $30 \mathrm{~min}$ at $45 \mathrm{~W}$ was performed before the application of the PCR samples. The molecular marker 50-bp DNA Ladder (Fermentas, USA) was loaded in the lateral extremities of each gel. The gels were stained with silver nitrate, as per the procedure described by Creste et al. (2001).

The 61 accessions were genotyped on 2 plates with polyacrylamide gels: one plate containing 54 accessions and the other containing the remaining accessions. On the first plate, at least 1 accession was identified and represented a genotype or allelic combination to be used as an allelic reference on the second gel plate for each microsatellite.

\section{Annotation and analysis of microsatellite data}

The size estimate in bp for each allele for the construction of allelic patterns for each accession was obtained by the inverse mobility method based on regression of products of known size of the 50-bp molecular marker (Fermentas). 
The microsatellites were analyzed for the presence (1) versus absence (0) of alleles to construct a similarity matrix of the Jaccard index. The dendrogram with distances of the accessions was designed based on the unweighted pair-group method using arithmetic average method. The adjustment of the dendrogram was evaluated using the cophenetic correlation, or more specifically, the correlation between the real distances and those represented graphically. For these analyses, the NTSYSpc (Rophlf, 1989) computer application was used. The frequency of the allele number, genotype number, gene diversity, heterozygosity, and polymorphic information content (PIC) for each microsatellite was estimated using the Power Marker (Liu and Muse, 2005) program.

\section{RESULTS}

Of the 16 microsatellite loci used, only 13 showed polymorphic amplifications of an easy interpretation: $\mathrm{mPgCIR} 227, \mathrm{mPgCIR} 233, \mathrm{mPgCIR} 242, \mathrm{mPgCIR} 243, \mathrm{mPgCIR} 246$, mPgCIR247, mPgCIR249, mPgCIR251, mPgCIR252, mPgCIR253, mPgCIR255, mPgCIR256, and $\mathrm{mPgCIR} 257$. Aranguren et al. (2010) studied the accession variability of 31 Venezuelan guava and reported that all 16 microsatellite loci were polymorphic. This reduction in the number of SSRs to detect polymorphisms can be used because, in the present study, these microsatellites were used for a joint evaluation of guava and araçazeiro belonging to $P$. guineense, $P$. cattleianum, and $P$. friedrichsthalianum species.

In all, 183 alleles were detected in the 13 microsatellites analyzed, and the number of alleles per locus ranged from 7 to 22, with an average of 14.07 alleles per microsatellite in the 61 accessions of genotyped Psidium. The size of the alleles ranged from $129 \mathrm{bp}$ in $\mathrm{mPgCIR} 33$ to 802 bp in mPgCIR247 (Table 2).

The largest number of genotypes was observed with microsatellite mPgCIR256, whereas the largest diversity of alleles was observed with microsatellite mPgCIR253 (Table 3 ); this finding is different from that reported by Aranguren et al. (2010), who used the same microsatellite set and found the largest diversity in microsatellite mPgCIR255.

The PIC values, which reflect the allelic diversity and frequency rate between accessions, were not uniform for all the microsatellite loci tested. The PIC average was 0.709 , with the largest and smallest values observed in loci mPgCIR253 (0.862) and mPgCIR233 (0.227), respectively (Table 3 ).

The average heterozygosity was 0.695 with loci mPgCIR227 and mPgCIR249 showing the largest values (1.000) and the locus mPgCIR233 showing the smallest (0.104) value (Table 3 ), indicating that the microsatellites showed a large variability detection capacity. The PIC and heterozygosity showed the existence of variability because each individual diploid could have up to 2 alleles per locus (Weir, 1996).

The identification of accessions with reference alleles for each microsatellite and its inclusion in the second gel polyacrylamide plate allowed a correct comparison and allelic identification of the remaining accessions. This strategy was adopted by Dos Santos Ribeiro et al. (2012), who evaluated 103 mango accessions by using 12 microsatellites.

The cophenetic correlation was 0.85 , which indicates that the dendrogram (Figure 1) presented a good adjustment in grouping Psidium accessions, with 183 alleles of 13 microsatellite loci analyzed. The similarity among accessions ranged from 0.75 to 1.00 , reflecting the existence of genetic variability in the accessions studied. Rodríguez-Medina et al. (2010) found similarity ranging from 0.40 to 1.00 among 43 accessions of a Cuban guava collection, which was evaluated using 7 microsatellite markers. High genetic variability was also found and reported by Corrêa et al. (2011) for 88 Psidium accessions of the same collection, evaluated using AFLP markers. 


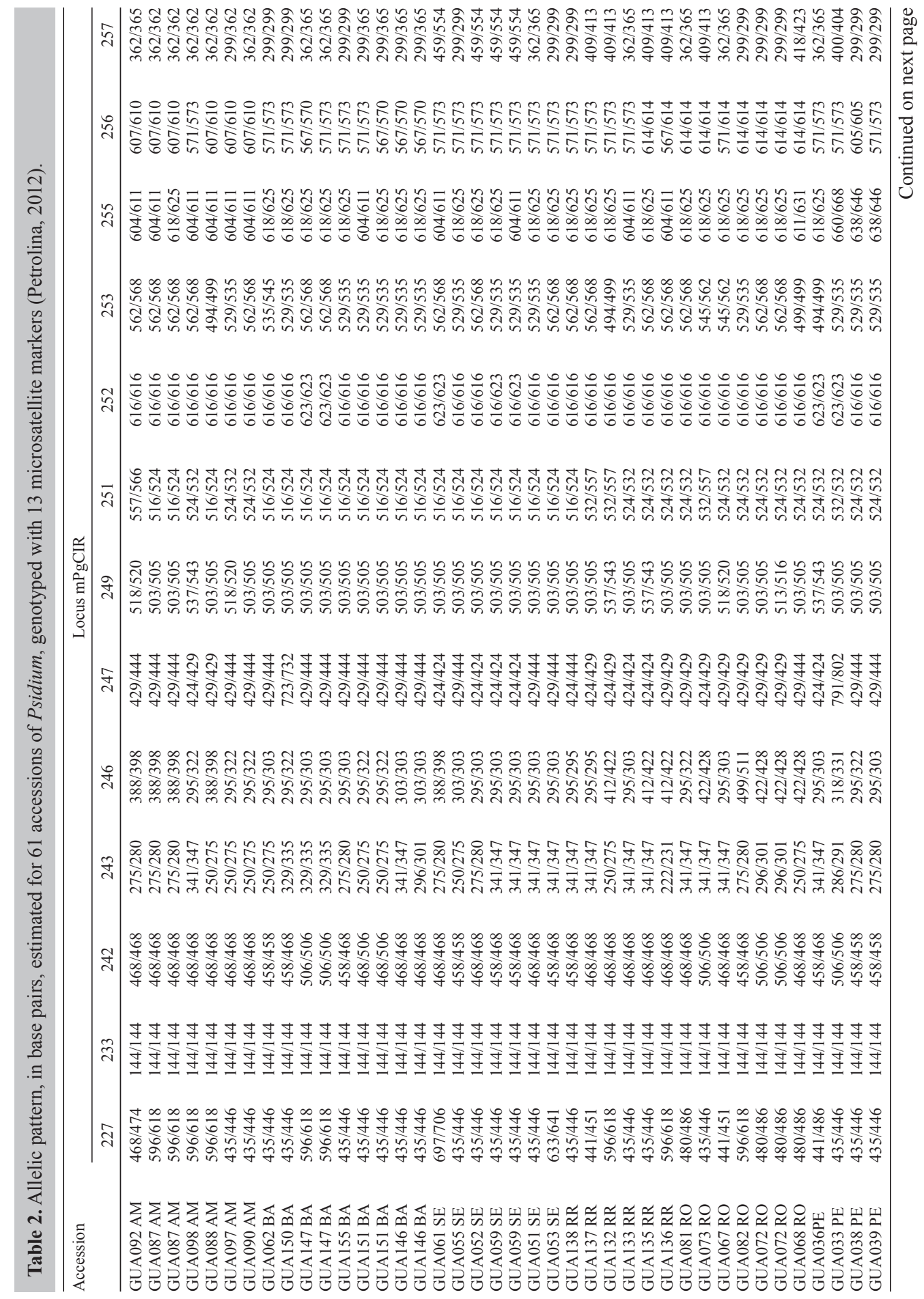




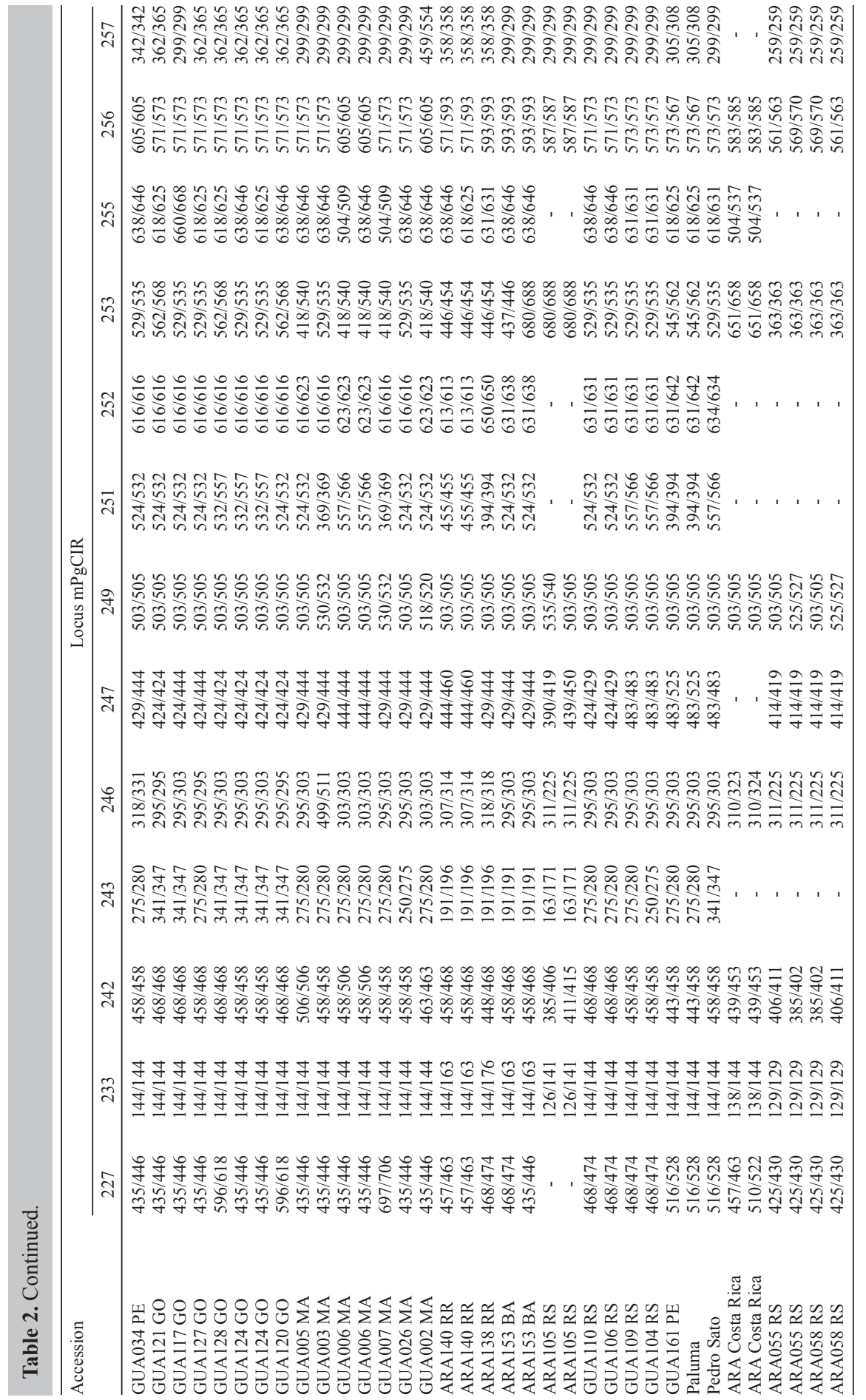


Table 3. Genetic parameters estimated for 13 microsatellites in 61 Psidium accessions (Petrolina, PE, 2012).

\begin{tabular}{|c|c|c|c|c|c|c|}
\hline SSR & Allelic frequency & No. of genotypes & No. of alleles & Genetic diversity & Heterozygosity & PIC \\
\hline mPgCIR227 & 0.233 & 12 & 22 & 0.869 & 1.000 & 0.858 \\
\hline mPgCIR233 & 0.873 & 6 & 7 & 0.233 & 0.120 & 0.227 \\
\hline mPgCIR242 & 0.453 & 14 & 13 & 0.696 & 0.373 & 0.652 \\
\hline mPgCIR243 & 0.239 & 10 & 17 & 0.859 & 0.971 & 0.844 \\
\hline mPgCIR246 & 0.313 & 14 & 19 & 0.814 & 0.840 & 0.794 \\
\hline mPgCIR247 & 0.329 & 14 & 15 & 0.771 & 0.671 & 0.737 \\
\hline mPgCIR249 & 0.407 & 7 & 14 & 0.666 & 1.000 & 0.608 \\
\hline mPgCIR251 & 0.351 & 8 & 8 & 0.773 & 0.881 & 0.741 \\
\hline mPgCIR252 & 0.679 & 9 & 8 & 0.509 & 0.104 & 0.481 \\
\hline mPgCIR253 & 0.193 & 12 & 17 & 0.874 & 0.933 & 0.862 \\
\hline mPgCIR255 & 0.239 & 9 & 12 & 0.846 & 0.957 & 0.829 \\
\hline mPgCIR256 & 0.273 & 15 & 15 & 0.840 & 0.733 & 0.824 \\
\hline mPgCIR257 & 0.404 & 13 & 16 & 0.782 & 0.452 & 0.762 \\
\hline Average & 0.384 & 11 & 14.1 & 0.733 & 0.695 & 0.709 \\
\hline
\end{tabular}

PIC $=$ polymorphism information content.

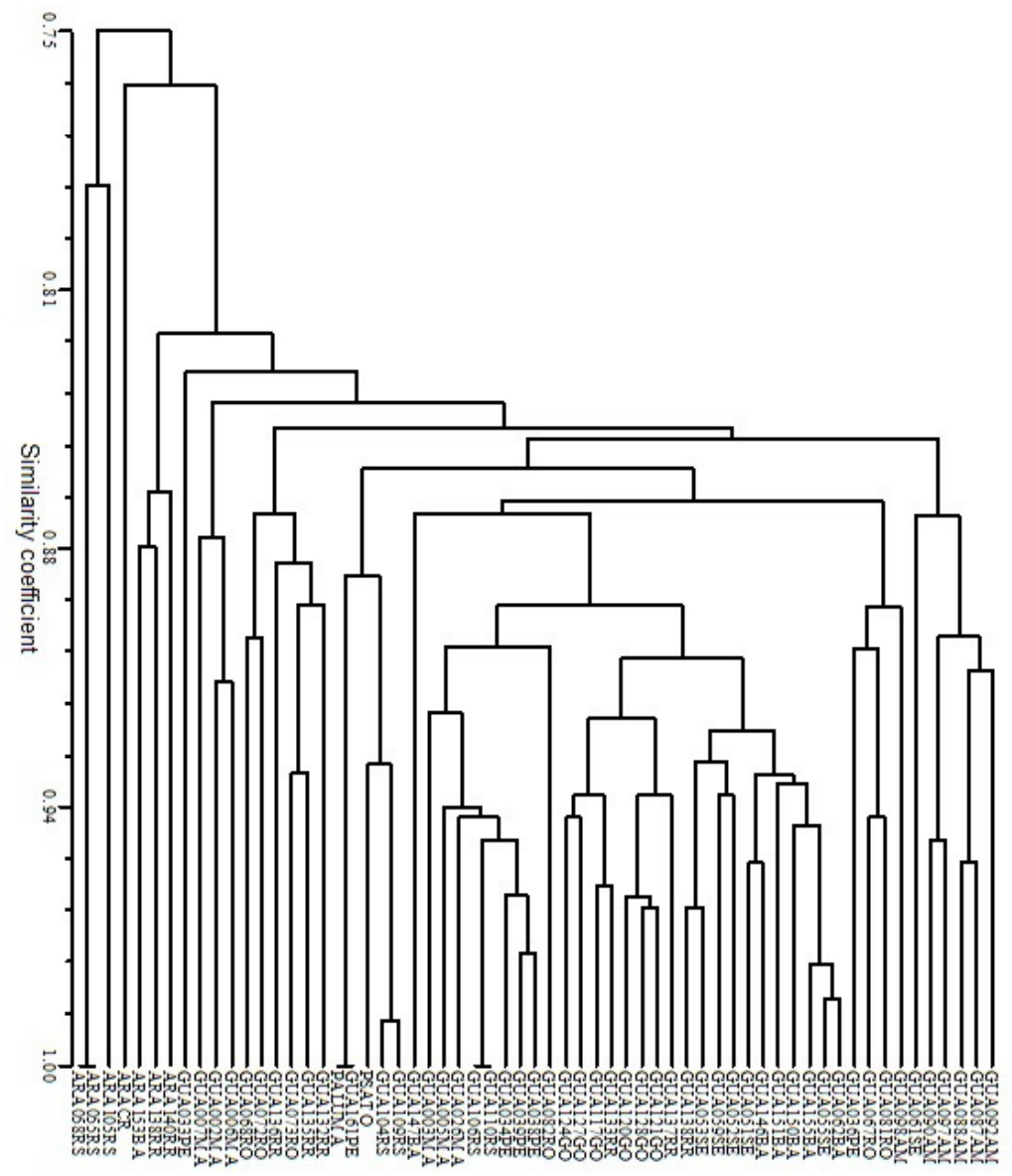

Figure 1. UPGMA dendrogram of the Jaccard coefficient among 61 accessions of Psidium of the Embrapa Semiárido Psidium germplasm collection sampled in nine Brazilian states and analyzed with 13 microsatellite loci. Cophenetic correlation $=0.85$. 
The 183 alleles of the 13 microsatellites were sufficient to separate the guava accessions from araçazeiro accessions. The cutting point at $83 \%$ of similarity led to the formation of 5 groups (Figure 1): Group I, from GUA92 to GUA33 PE; group II, from ARA140 RR to ARA153 BA; group III, formed exclusively by the accession ARA Costa Rica; group IV, formed only by the accession ARA105 RS; and group V, formed by accessions ARA055 RS to ARA058 RS. Group I predominantly included guava accessions, while group II included only accessions of the species $P$. guineense. Groups IV and V included $P$. cattleianum, while group III included P. friedrichsthalianum. The external localization of the araçazeiro accessions in relation to the guava group was an indication for the adequacy of the dendrogram generated.

\section{DISCUSSION}

Largest similarities (100\%) were observed between ARA55 RS and ARA58 RS and GUA110 RS and GUA106 RS accessions, probably because they were sampled at the same BAG, at Pelotas, RS. The GUA161 PE accession and Paluma cultivar, besides showing morphologically divergent characteristics, were genetically equal to the loci analyzed, with an observed similarity of $100 \%$ (Figure 1). The GUA161 PE accession was considered to be an amphidiploid (data not shown), which might explain the $100 \%$ similarity. Additional analyses with other microsatellites and further cytogenetic studies are indicated to elucidate this similarity between GUA161 PE and Paluma.

Guava accessions belonging to the States of Bahia, Sergipe, and Goiás in group I were almost positioned sequentially in the branches of the dendrogram (Figure 1), suggesting a remarkable genetic similarity between the accessions. The 7 araçazeiro accessions ARA140 RR, 138 RR, and ARA153 BA (P. guineense); ARA105 RS, 55 RS, and 58 RS ( $P$. cattleianum); and ARA of Costa Rica (P. friedrichsthalianum) - were positioned at the base of the dendrogram, suggesting greater similarity among them. Briceño et al. (2010) found the same separation pattern among Venezuelan guava accessions and other species of Psidium, such as $P$. guineense, all of which were evaluated using microsatellite markers. HernándezDelgado et al. (2007) analyzed 52 Psidium accessions of a Mexican collection and reported a dendrogram with 2 groups: the first comprising P. cattleianum and P. friedrichsthalianum accessions and the second comprising P. guajava accessions.

Crossing is possible among the ARA140 RR, ARA138 RR, and ARA153 BA accessions and guava accessions that showed $82.4 \%$ similarity. These data are supported by the results that were obtained by da Costa et al. (2012), who reported successes with interspecies hybrids between $P$. guajava and $P$. guineense and unsuccessful hybridization of other species of Psidium with guava accessions.

Variability among guava accessions was $0.238\left(\Phi_{\mathrm{ST}}\right.$; Table 4$)$, with a genetic differentiation that was considered to be high, indicating a high variability among the accessions analyzed. Although guava is considered to have a tendency of a high cross-pollination rate (Alves and Freitas, 2007), the gene flow among the accessions collected from 9 Brazilian states was small and considered to be restricted, probably due to the limited flow of germplasm for those accessions that were not cultivated on a commercial scale. Higher results of $\Phi_{\text {ST }}=0.355$ were also reported by Sanabria et al. (2006) for 53 accessions of 9 Colombian guava populations. 
Table 4. Analysis of molecular variance (AMOVA) for 51 guava accessions collected in nine Brazilian states and evaluated with 183 SSR alleles.

\begin{tabular}{|c|c|c|c|c|c|c|}
\hline Variation source & d.f. & SS & MS & Variation total* & Statistical $\Phi$ & $\mathrm{P}$ \\
\hline Between accessions & 8 & 217.3 & 27.1 & $24 \%$ & $\Phi_{\mathrm{ST}}=0.238$ & $<0.001$ \\
\hline Within accessions & 43 & 417.5 & 9.7 & $76 \%$ & $1-\Phi_{\mathrm{ST}}^{\mathrm{ST}}=0.762$ & $<0.001$ \\
\hline Total & 51 & 634.8 & - & $100 \%$ & & \\
\hline
\end{tabular}

*Probability based on 1000 permutations.

The dendrogram (Figure 1) and AMOVA (Table 3) results suggested that the genetic variability in guava was not uniformly dispersed among the 9 Brazilian states, indicating that geographical barriers, edaphoclimatic conditions, predominance of self-mating in guava, or even cutting-free germplasm dispersion have limited the exchange of alleles among guava orchards. Therefore, a greater number of accessions should be sampled by Brazilian states in order to have greater diversity among guava species.

\section{REFERENCES}

Alves JE and Freitas BM (2007). Requerimento de polinização da goiaba. Cienc. Rural 37: 1281-1286.

Aranguren Y, Briceño A and Fermin G (2010). Assessment of the variability of Venezuelan guava landraces by microsatellites. Acta Hortic. 849: 147-154.

Briceño A, Aranguren Y and Fermin G (2010). Assessment of guava-derived SSR markers for the molecular characterization of Myrtaceae from different ecosystems in Venezuelan. Acta Hortic. 849: 139-146.

Corrêa LC, Santos CAF, Lima GPP, Rodrigues MA, et al. (2011). Similaridade genética entre acessos de goiabeiras e araçazeiros baseada em marcadores moleculares AFLP. Rev. Bras. Frutic. 33: 859-867.

Creste S, Tulmann Neto A and Figueira A (2001). Detection of single sequence repeat polymorphisms in denaturing polyacrylamide sequencing gels by silver staining. Plant Mol. Biol. Rep. 19: 299-306.

da Costa SR, Santos CAF and Castro JMC (2012). Assessing Psidium guajava x P. guineense hybrids tolerance to Meloidogyne enterolobii. Acta Hortic. 959: 59-65.

Dos Santos Ribeiro IC, Lima Neto FP and Santos CA (2012). Allelic database and accession divergence of a Brazilian mango collection based on microsatellite markers. Genet. Mol. Res. 11: 4564-4574.

Doyle JJ and Doyle JL (1990). Isolation of plant DNA from fresh tissue. Focus 12: 13-15.

Erig AC, Schuch MW, Raseira MCB, Vighi IL, et al. (2003). RAPD molecular marker in the evaluation of genetic diversity in araçazeiro. Rev. Cienc. Rural 8: 101-106.

Esselink GD, Smulders MJ and Vosman B (2003). Identification of cut rose (Rosa hybrida) and rootstock varieties using robust sequence tagged microsatellite site markers. Theor. Appl. Genet. 106: 277-286.

Gonzaga Neto L (1999). Melhoramento Genético da Goiabeira. In: Recursos Genéticos e Melhoramento de Plantas para o Nordeste Brasileiro Embrapa Semi-Árido/Brasília and Embrapa Recursos Genéticos e Biotecnologia, Petrolina.

Hernández-Delgado S, Padilla-Ramírez JS, Nava-Cedillo A and Mayek-Perez N (2007). Morphological and genetic diversity of Mexican guava germplasm. Plant Genet. Res.: Characterization and Utilization 5: 131-141.

IBGE (2011). Produção Agrícola Municipal. Available at [http://www.sidra.ibge.gov.br]. Accessed September 28, 2012.

Liu K and Muse SV (2005). PowerMarker: an integrated analysis environment for genetic marker analysis. Bioinformatics 21: $2128-2129$

Negi SS and Rajan S (2007). Improvement of guava through breeding. Acta Hortic. 735: 31-37.

Pessanha PGO, Viana AP, Júnior ATA, Souza RM, et al. (2011). Avaliação da diversidade genética em acessos de Psidium ssp. via marcadores RAPD. Rev. Bras. Frutic. 33: 129-136.

Raseira MCB and Raseira A (1996). Contribuição ao Estudo do Araçazeiro: Psidium cattleyanum. Embrapa-CPACT, Pelotas.

Risterucci AM, Duval MF, Rohde W and Billote N (2005). Isolation and characterization of microsatellite loci from Psidium guajava L. Mol. Ecol. Notes 5: 745-748.

Rodríguez-Medina NM, Valdés-Infante J, Velásquez B, Rivero D, et al. (2010). Individual versus combined data set for molecular characterization of Cuban guava (Psidium guajava) germplasm. Acta Hortic. 849: 163-172. 
Rophlf FJ (1989). NTSYS-pc Numerical Taxonomy and Multivariate Analysis System, Version 1.80. Editora Exeter Software, Setauket.

Sanabria HL, Garcia MA, Muñoz JE and Díaz H (2006). Caracterización molecular con marcadores RAM de árboles nativos de Psidium guajava (guayaba) en el Valle del Cauca. Acta Agron. 55: 1-8.

Sánchez-Teyer LF, Bazarra-Morales A, Keb L, F Barredo, et al. (2010). Assessment of genetic diversity of Mexican guava germplasm using DNA molecular markers. Acta Hortic. 849: 133-138.

São José AR, Rebouças TNH, Dias NO, Hojo RH, et al. (2003). Cultivo de Goiabeira no Brasil. In: Primer Simpósio Internacional de La Guayaba. Memoria Aguascalientes, Aguascalientes.

Singh G (2007). Recent development in production of guava. Acta Hortic. 735: 161-176.

Souza RM, Nogueira MS, Lima IM, Melarato M, et al. (2006). Manejo de nematóides das galhas da goiabeira em São João da Barra (RJ) e relato de novos hospedeiros. Nematol. Bras. 30: 165-169.

Valdés-Infante J, Rodriguéz NN, Becker D, Velázquez B, et al. (2007). Microsatellite characterization of guava (Psidium guajava L.) germplasm collection in Cuba. Cultivo Tropicales 28: 61-67.

Weir BS (1996). Genetic Data Analysis II - Methods for Discrete Population Genetic Data. Sinauer Associates, Sunderland. 